\title{
Changing Agricultural Practices and Indigenous Food Crops in the Upper Afram Basin of Ghana
}

\author{
F. BAA-POKU*, J. S. AYIVOR \& B. D. OFORI \\ (F.B-P.: Department of Environmental Management and Technology, Koforidua Technical \\ University, P. O. Box KF 981 Koforidua, Eastern Region, Ghana; J.S.A, \& B.D.O.: IESS, \\ University of Ghana, Legon) \\ *Corresponding author 's email: frimpomahbp@gmail.com
}

\begin{abstract}
The Forest Savanna Transition zone within which the Upper Afram basin lies, account for a wide variety of food crops and plant species. This study examined the effects of changing agricultural practices on cultivation and availability of indigenous food crops within the basin. Qualitative data obtained from 240 farmers through individual interviews and Focus group discussions were analyzed thematically. The study revealed that even though the farmers employed the traditional mixed cropping system, the widespread use of agro-chemicals in the study area was limiting the practice of intercropping. This accounts for the current dominance of mono cropping system in the study area. These changes have affected the cultivation of a wide variety of indigenous foods within the basin. The uncontrolled use of agro-chemicals constituted one of the major agronomic constraints affecting the cultivation of these crops. Adequate technical support services to effectively control agrochemical abuse among the local farmers will, therefore, be required. Increased sensitization on the need for local farmers to refocus and maintain some of the traditional agricultural practices that ensured the cultivation of a wide variety of indigenous food crop varieties (NUCS) in their farms is also suggested.
\end{abstract}

Keywords: Forest Savanna Transition zone; Upper Afram basin; Indigenous food crops; Agronomic practices; Farming systems;

Original scientific paper. Received 10 Nov 2019; revised 26 May 2020

\section{Introduction}

Human dependence on agriculture for survival can be traced back to prehistoric times. Hunting, fishing and food gathering constituted the main source of livelihood. This approach to human sustenance evolved with the cultivation of wild plants and domestication of wild animals (Chandrasekaran et al., 2010). Traditional farmers subsequently have focused on the cultivation of a wide range of indigenous crops and livestock breeds to meet the food and livelihood needs of households (Stefanie
\& Amend, 2008). Indigenous food crops were produced primarily based on the farmer's experience and indigenous knowledge of seasonal changes and environmental conditions (Maroyi, 2011). The application of indigenous knowledge in the cultivation of traditional food crops also ensured the sustenance of local culture, livelihoods and community resilience (Shava et al., 2009). Chivenge et al. (2015) further note that the cultivation of indigenous crops and plant species enhances genetic biodiversity and food security. Apart from their

Ghana Jnl Agric. Sci. 55 (1), 65 - 74

GJAS is an Open Access Journal and distributed under the terms of the Creative Commons (CC) License [CC BY 4.0] 
role in maintaining cultural diversity among local communities, indigenous crops constitute an important component of agrobiodiversity (IPGRI, 2002). Their ability to thrive under harsh conditions makes them useful in climate change mitigation (Bala Ravi et al., 2006). In India, indigenous crops are cultivated mainly as mixed or intercropped with other fodder yielding cereals such as maize, grain legumes and sorghum (Bala Ravi et al., 2010). Machakaire et al. (2000) also assert that most indigenous vegetables in Zimbabwe thrive well under the traditional system of mixed cropping. In Ghana, as in many other West African countries, the intercropping system constituted the main system of farming for several years. The traditional intercropping system ensured the cultivation and availability of a diverse range of indigenous crops. However, practices such as bush burning, uncontrolled use of agro chemicals, inappropriate tillage and water management practices are constraining agricultural production (MoFA, 2007). Mass use of systemic weedicides and the lack of knowledge of the conservation of seeds and tubers of indigenous crop varieties have been identified to be key factors in the genetic erosion of these crops (Nyadanu et al., 2015). The gradual erosion of these crops has also been linked with agricultural intensification and policy issues (Bala Ravi et al., 2010). Lopez-Noriega et al. (2017) also note that the change in agricultural systems which now emphasises the cultivation of high-input and high-yielding crop species has led to the reliance on a few priority crops such as rice, wheat and maize. In Ghana, agri- cultural systems now emphasise the cultivation and promotion of high yielding staple crops often resulting in the marginalization of other local food crop varieties and plant species. The Upper Afram basin which lies within the Forest Savanna Transition zone of Ghana is known for its relatively rich agrodiversity and intense agricultural activity. The agroecology account for the wide variety of food crops and plant species. However, the extent to which the prevailing farming systems and agronomic practices are influencing the cultivation of indigenous food crops in the basin is not well known. This study, therefore, examined the effect of changing agricultural practices on the cultivation and availability of indigenous food crop varieties and plant species in some communities within the basin.

\section{Materials and Methods \\ Study Area}

The study was conducted in the Upper Afram basin, which lies within the Forest-Savannah Transition Zone of Ghana (Figure 1). The Forest-Savannah Transition Zone is located within the middle portion of the Brong Ahafo Region, the northern part of both Ashanti and Eastern regions and the western part of the Volta Region. This zone is considered as the food hub of the country and hence offers great potential for increased food productivity. The basin has an annual average temperature of about $28^{\circ} \mathrm{C}$ (Ayivor et al., 2016) with average annual rainfall ranging between $1200 \mathrm{~mm}$ and $1300 \mathrm{~mm}$. 


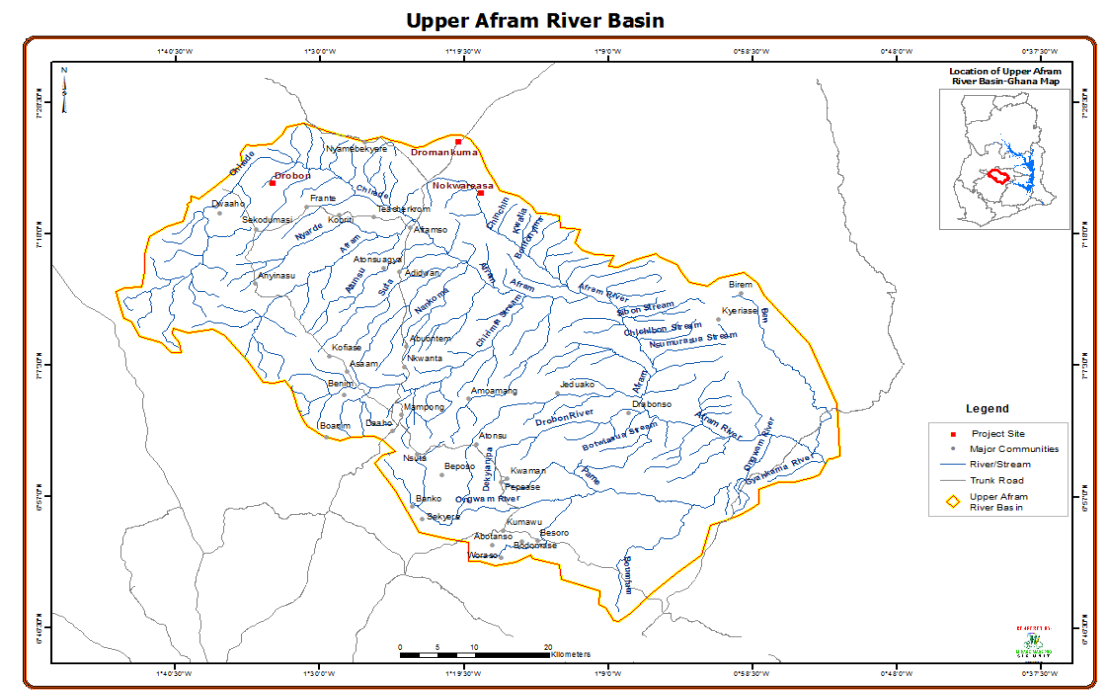

Figure 1: Study sites in the Upper Afram Basin

Source: CERGIS

Its population is made up of largely indigenous Asante and migrants from the northern parts of Ghana (Ayivor \& Ntiamoa-Baidu, 2015). Farming is the primary activity among inhabitants within the basin. Three study communities comprising mainly of agricultural households, mostly engaged in crop farming were selected for the study. The communities include Nokwareasa, Dromankuman and Drobon.

\section{Design}

A qualitative research design was deemed to be most appropriate for the study due to the nature of the research objectives. Creswell (2009) describes qualitative research as a research approach that seeks to explore and understand the meaning individuals or groups ascribe to a phenomenon. The study primarily sought to understand and provide rich descriptions of the phenomenon. The qualitative approach was therefore employed to elicit indigenous knowledge from the local farmers in the study area.

\section{Sampling approach}

240 farmers with over 15 years' experience in farming were purposively selected from the three study communities. The farmers who comprised both males and females were identified with the assistance of the agricultural extension officers from the Ministry of Food and Agriculture (MoFA) offices and other community leaders within the study area.

\section{Data Collection and analysis}

Focus group discussions and individual interviews were used to collect primary data. Prior to the interviews, reconnaissance visits were made to the study area to seek both formal and verbal consent from the relevant institutions and the potential respondents. The qualitative data were analyzed using thematic analysis. All the audio-recorded interviews 
were transcribed and themes identified and presented in descriptive forms. Trustworthiness and credibility of the research data were achieved through the use of multiple data collection instruments, including focus group discussions and individual interviews. Detailed transcription of audio recorded interviews and thorough descriptions of transcribed data were carried out. These were intended to cross-check and guarantee the accuracy and consistency of the data collected.

\section{Results and Discussion}

\section{Farming systems}

Indigenous farming systems

Interviews with farmers on the indigenous farming systems employed in the communities studied indicated that farming within the Upper Afram basin occurred on a subsistence level. Households easily acquired lands for crop cultivation due to the availability of large tracts of lands and the proximity of the farm lands to their places of residence. Rotational bush fallowing was extensively practiced within the basin. Majority of the farmers reported that two main traditional cropping systems were employed in the past, mixed cropping and monocropping. The traditional mixed cropping which was the most commonly practiced in the basin, enabled farmers to cultivate diverse food crops. This also reduced the risk of losing all crop produce or yields. Similar assertions by Machakaire et al. (2000) and Bala Ravi et al. (2010) have both suggested that indigenous crops thrive well under the traditional mixed cropping system. Mabhaudhi et al. (2016) have also argued that indigenous crops in Southern Africa are found in cropping systems across the entire major agro-ecological zones. In the Upper Afram basin, however, only a few small holder farms currently engage in mixed cropping despite its known contribution to crop diversity.

\section{Changing farming system}

On the prevailing farming systems employed within the basin, the farmers pointed to a significant shift from the traditional mixed or intercropping system to the monocropping system. The monocropping system is however practiced mainly by a few commercial farms. Among some of the commercial farms identified included, the National Service Scheme Farms - a 500-acre maize farm; Pee farms 1000-acre maize and beans farm and the Ejura Camp Prison farm. However, the farmers also reported that the introduction of agrochemicals in crop production has largely influenced majority of the farmers to lean towards the monocropping system. Exposure to selected food crops with high yielding varieties by officers from MoFA and the Council for Scientific and Industrial Research-Crops Research Institute (CSIR-CRI) also influenced the decision to adopt the monocropping system. This subsequently has resulted in the gradual erosion or marginalization of indigenous food crop varieties in the study areas.

\section{Agronomic practices}

Traditional agronomic practices

With regards to the traditional agronomic practices, the farmers listed common practices such as the use of cutlass and hoe for land preparation and weed control; seed sowing through broadcasting by hand especially for cereals; the use of local materials such as cow dung, ash, solutions of Neem to control pests; use of local materials such as chicken droppings, livestock droppings or organic materials for soil fertility; hand harvesting of crops; and the use of barns or local silos for crop storage. These simple traditional practices are being replaced by new 
farming practices. Table 1 presents an overview of the indigenous and current agronomic practices elicited from interviews with the farmers.

\section{The prevailing agronomic practices}

The farmers reported that indigenous agronomic practices are gradually giving way to new farming practices (Table 1). Majority of the farmers had moved away from the manual means of land preparation to tractor ploughing. This according to them has resulted in the increased demand for tractor services, especially during the peak seasons. Tractor services are therefore solicited from the Northern regions into Ejura in the Upper Afram basin to support those periods.

TABLE 1

Summary of agronomic practices employed in the study communities

\begin{tabular}{|c|c|c|c|c|}
\hline$S / N$ & $\begin{array}{l}\text { Agronomic } \\
\text { Activity }\end{array}$ & Previous practice & Current practice & $\begin{array}{l}\text { Possible Negative Effect of current } \\
\text { practices on Soil/Crops (NUCS) }\end{array}$ \\
\hline 1. & Land preparation & Use of cutlass and hoe & $\begin{array}{l}\text { Use of total non-selective } \\
\text { herbicides; Use of tractors } \\
\text { especially in Upper Afram } \\
\text { Basin (UAB). }\end{array}$ & $\begin{array}{l}\text { Threat to biodiversity; Destroys wild to } \\
\text { semi-natural habitats (Pesticide Action } \\
\text { Network Europe PAN, 2017). }\end{array}$ \\
\hline 2. & Sowing & $\begin{array}{l}\text { Broadcasting by hand } \\
\text { eg. cereals and seeds }\end{array}$ & $\begin{array}{l}\text { Use of pole and line for } \\
\text { planting; Use of planters } \\
\text { mainly for maize UAB (by } \\
\text { a few people). }\end{array}$ & \\
\hline
\end{tabular}

Management Practices

\begin{tabular}{|c|c|c|c|c|}
\hline 3 & Weed control & Use of cutlass or hoe & Use of selective weedicides & $\begin{array}{l}\text { Disrupt functional soil structures and } \\
\text { pollination services (PAN, 2017) }\end{array}$ \\
\hline 4. & Pest control & $\begin{array}{l}\text { Use of local materials } \\
\text { such as cow dung, } \\
\text { ash, solutions of } \\
\text { neem, etc; } \\
\text { Practice of crop } \\
\text { rotations. }\end{array}$ & $\begin{array}{l}\text { Use of pesticides } \\
\text { (insecticides, rodenticides, } \\
\text { etc.) }\end{array}$ & $\begin{array}{l}\text { Agrochemical use increases likelihood of } \\
\text { pest outbreaks }\end{array}$ \\
\hline 5. & Soil enhancer & $\begin{array}{l}\text { Using local materials } \\
\text { such as chicken } \\
\text { droppings, livestock } \\
\text { droppings or organic } \\
\text { materials; } \\
\text { Through crop } \\
\text { rotations and fallow } \\
\text { periods. }\end{array}$ & Use of chemical fertilizers & $\begin{array}{l}\text { Agrochemical usage introduces foreign } \\
\text { weeds, which rather deplete the soils } \\
\text { of moisture and nutrient. (Baishya, K, } \\
\text { 2015); } \\
\text { Continuous fertilizer application can lead } \\
\text { to acidification of soil which affects most } \\
\text { crops (Ogbodo \& Onwa, 2013); } \\
\text { Can cause significant variations in the } \\
\text { populations of soil micro-organisms } \\
\text { (Ogbodo \& Onwa, 2013) }\end{array}$ \\
\hline 6. & Harvesting & Hand harvesting & $\begin{array}{l}\text { Hand harvesting; } \\
\text { Use of harvesters for maize }\end{array}$ & $\begin{array}{l}\text { Unsustainable harvesting of leaves and } \\
\text { bark can affect the survival rate of the } \\
\text { crop or population size over the long } \\
\text { term (Cocks \& Dold (2004); Gaoue \& } \\
\text { Ticktin, (2008) }\end{array}$ \\
\hline 7. & Storage & $\begin{array}{l}\text { Kept in barns with } \\
\text { warmth or local silos. }\end{array}$ & $\begin{array}{l}\text { Preserved with } \\
\text { agrochemicals }\end{array}$ & \\
\hline 8. & Watering & Rain-fed & Rain-fed & $\begin{array}{l}\text { Rainfall variability leads to poor growth } \\
\text { and low crop yield (Mkonda, 2014) }\end{array}$ \\
\hline
\end{tabular}


Mechanized farming which involves tractor ploughing was found to be relatively prominent on large commercial farms in the study area. Even though the tractor ploughing seemed more efficient, its adverse effect on the cultivation of some food crops such as yam which requires the presence of trees that serve as stakes was a source of concern. Tractor ploughing creates ridges which leads to soil erosion. Harrowing, a process that involves the loosening of the soil is the common way of addressing this problem created by the ploughing process. Most farmers however are not able to bear the cost of harrowing and are therefore compelled to plant on the ridges. This potentially reduces the number of seeds that can be cultivated on a hectare of farm land thereby affecting yields. The activity of seed sowing which involved broadcasting of seeds by hand especially for cereals is currently giving way to the use of the pole and line method; and planters particularly for maize cultivation. Selective weedicides are now commonly used in weed control. The spraying of weedicides on the field, soon after planting, helps to suppress the emergence of weeds. This ensures that the crops attain a certain height before the weeds begin to grow and compete with them. Due to the extensive use of agrochemicals in weed control, the practice of mulching has reduced considerably. The mulching process ensured the conservation of soil moisture, regulation of soil temperature, prevention of erosion, suppression of weed growth and soil fertility (Sharma \& Bhardwaj, 2017). Pest control that traditionally involved the use of local materials such as cow dung, ash, solutions of neem seed (Azadirachtin) extract are also not commonly used now due to the introduction of pesticides including insecticides and rodenticides. Crop rotation and the fallow periods allowed farm lands to regain their fertility. The application of local materials such as chicken droppings, livestock droppings, or organic materials also helped in enriching the soil. These practices however have declined due to the introduction and use of chemical fertilizers for soil fertility. The use of ashes as a form of "insecticide" for the cultivation of food crops such as okro and beans has been replaced by insecticide such as Dichlorodiphenyltrichloroethane (DDT). Neem was used as an insecticide, whilst chicken droppings served as fertilizers. These forms of "natural insecticides", according to the farmers, are no more in use due to the need to secure relatively large farm produce from pest invasion and destruction. Farming in the study area is basically rainfed with a few individual farms resorting to the use of other sources of water including small scale irrigation systems. Harvesting of crops which were carried out manually using family labour has been replaced largely by harvesters, especially for the large commercial farms. Harvested food crops were kept in local silos or barns which provided warmth. This notwithstanding, post-harvest loss continues to be a major challenge in the study area. The use of agrochemicals for crop preservation has also replaced the old methods of crop preservation.

\section{Agrochemical use}

The use of agrochemical to boost agricultural production is widely acknowledged as it guarantees and enhances agricultural productivity (Omari, 2014). In Ghana, agrochemical abuse, particularly pesticides, remain a major source of concern given the attendant adverse effects on human health and the environment (Asante $\&$ Ntow, 2009). Majority of the local farmers indicated that, although the introduction of agrochemicals has enhanced crop production and made land preparation much easier, its 
attendant adverse effect on their health was a source of concern. The adverse effects of the chemicals on some particular crops such as pineapple, cocoyam, Misewa (Pepper), Yaa Asantewaa (Solanum sp.), Nsusua (Solanum $s p$.) among others were also recounted. The farmers reported that lands that hitherto were not suitable for crop cultivation are now usable. A typical example cited by a local farmer is sugarcane lands. The use of agrochemicals for crop production in the study communities can be traced to its first application to cowpea cultivation during a demonstration exercise by Adventist Development and Relief Agency (ADRA) in 2013. Total weed killer for example was used for clearing weeds in swampy areas. Fertilizers and pesticides are the commonly used agrochemicals in the area. The pesticides identified during the study include insecticide, herbicides, weedicide and fungicides. These pesticides belonged to category II and III of WHO/FAO classification of pesticides which are known to be moderately and slightly hazardous chemicals respectively (Table 2).

TABLE 2

Mostly used pesticides by farmers in the Upper Afram basin, active ingredients and WHO/FAO classification

\begin{tabular}{llll}
\hline Types of pesticides & Common name & Active ingredients & $\begin{array}{l}\text { WHO/FAO } \\
\text { classification }\end{array}$ \\
& Shye nwura & $41 \%$ glyphosate/l & III \\
Condemn & Glyphosate $41 \%$ & III \\
Atrazine liquid & Atrazine $500 \mathrm{G} / \mathrm{L}$ SC & III \\
Kabasate red & Glyphosate $480 \mathrm{~g} / 1$ & III \\
& Power & Fenoxaprop-p-ethyl 10 EC & O \\
& Lambda & Lambda-cyhalothrin 50 & II \\
& Confidor & g/L & II \\
Sampiriphos & Imidacloprid & II \\
Sunpyriphos & Chlorpyrifos ethyl & II \\
k-optimal & Lambda-cyhalothrin + & \\
& Eradicot T & Acetamiprid &
\end{tabular}

Note: $I I=$ moderately hazardous; $I I I=$ slightly hazardous; $O=$ Obsolete as pesticide, not classified

\section{Changing farming practices and indigenous food crops}

The current preference for high-input and high-yielding crop species arising from changing agricultural systems has led to the emphasis on the cultivation of selected staples such as rice, wheat and maize (Lopez-Noriega et al.,
2017). Following this paradigm shift in agricultural systems, Ghana now emphasizes the cultivation of selected high yielding staples. Changing farming practices and the consequent effect on agricultural production as reported by the local farmers in some farming communities in the study area give credence to this assertion. The study revealed that agrochemical 
abuse constitutes one of the major agronomic constraints affecting the continuous availability of indigenous food crops in the study area. Widespread use of the chemicals is affecting the availability of the indigenous crops and their wild relatives as these crops are deprived of their natural and undisturbed environments in which they thrive. Agrochemical use is also associated with foreign weeds, which deplete the soils of moisture and nutrient (Baishya, 2015). The study found that the application of agrochemicals (weedicides) on farms resulted in the destruction of both farm crops and weeds thereby destroying some of the indigenous crops in the study area. These observations are consistent with the findings of Nyadanu et al. (2015) who identified factors such as the increased use of systemic weedicides as being responsible for the genetic erosion of indigenous crops.

\section{Conclusion}

Farmers in the Upper Afram basin have over the years employed various traditional farming practices in the cultivation of their food crops. The study findings showed that traditional agroforestry and the traditional mixed cropping system employed by the farmers over the years ensured the availability of a wide range of indigenous food crops for households. The study also established, however, that the widespread use of agrochemicals among the farmers for crop production was limiting the practice of the traditional mixed cropping system. Agrochemical abuse was found to be widespread among the farmers and this constituted one of the major agronomic constraints affecting the cultivation of the indigenous crops. Agrochemical use had significantly affected the traditional agronomic practices employed by the farmers within the study basins. The study concluded that the changing farming systems and the gradual shift from the traditional agronomic practices by the farmers have to a large extent affected the continuous availability of indigenous food crops within the study basins. These notwithstanding, the cultivation of some of these crops were found in certain areas. The provision of adequate technical support services to control agrochemical abuse among farmers at the district and community levels will, therefore, be required. It is also recommended that the local farmers are sensitized to refocus and maintain some of the traditional agricultural practices that ensured the cultivation of a wide variety of indigenous food crop varieties (NUCS). These findings are imperative as they provide an understanding of the phenomenon and an indication of the extent to which indigenous food crops are being marginalized as a result of the changing agricultural practices in the Upper Afram basin.

\section{REFERENCES}

Ayivor, J. S., Pabi O., Ofori B. D., Yirenya-Taiwiah D. R. \& Gordon C. (2016) Agro Diversity in the Forest-Savannah Transition Zone of Ghana: A Strategy for Food Security against Climatic and Socio-Economic Stressors. Environment and Natural Resource Research 6 (1).

Ayivor, J. S. \& Ntiamoa-Baidu, Y. (2015) Assessing the socio-economic stressors of Ghana's only Strict Nature Reserve - Kogyae. Parks, 21 (2), $88-101$.

Asante, K.A. \& Ntow, W. J. (2009) Status of Environmental Contamination in Ghana, the perspective of a research Scientist. Interdisciplinary Studies on Environmental Chemistry - Environmental Research in Asia, 253 - 260.

Bala Ravi, S., Hoeschle-Zeledon, I., Swaminathan, M. S. \& Frison, E. (Eds.) (2006) Hunger 
and Poverty: The Role of Biodiversity. MS Swaminathan Research Foundation and IPGRI, India and Rome, pp. 232.

Bala Ravi, S., Hrideek, T.K., Kishore Kumar, AT., Prabhakaran, TR., Mal, B. \& Padulosi, S. (2010). Mobilizing Neglected and Underutilized Crops to Strengthen Food Security and Alleviate Poverty in India. Indian Journal of Plant Genetic Resources 23(1), 110 - 116.

Baishya, K. (2015) Impact of agrochemicals application on Soil quality degradation-a review. $2^{\text {nd }}$ International Conference on Science, Technology and Management. University of Delhi. New Delhi, India.

Chandrasekaran, B., Annadurai, K. \& Somasundaram, E. (2010) A textbook of agronomy. New Delhi: New Age International (P) Ltd., Publishers.

Chivenge, P., Mabhaudhi, T., Modi, A. T. \& Mafongoya, P. (2015) The potential role of neglected and underutilised crop species as future crops under water scarce conditions in Sub-Saharan Africa. International Journal of Environmental Research and Public Health 12 (6), 5685 - 5711.

Cocks, M. \& Dold, T. (2004) The informal trade of Cassipourea flanaganii as a cosmetic in South Africa, in: Sunderland, T., Ndoye, O. (Eds.), Forest products, livelihoods and conservation. Case studies of non-timber forest product systems. Africa. CIFOR, Bogor 2, 73 - 90.

Creswell, J. (2009) Research design qualitative, quantitative and mixed methods approaches. Los angeles: Sage Publications.

Gaoue O. G. \& Ticktin T. (2008) Impacts of bark and foliage harvest on Khaya senegalensis (Meliaceae) reproductive performance in Benin, Journal of Applied Ecology 45 (1), $34-40$.
International Plant Genetic Resources Institute (IPGRI). (2002) Neglected and underutilized plant species: Strategic action plan of the International Plant Genetic Resources Institute. Rome: IPGRI.

Josephson A. L., Ricker-Gilbert, J. \& Florax J.G.M. (2014) How does population density influence agricultural intensification and productivity? Evidence from Ethiopia. Food Policy 48, $142-152$.

López-Noriega, I., Dawson I.K., Vernooy, R, KöhlerRollefson, I. \& Halewood, M. (2017) Agricultural diversification as an adaptation strategy. Agriculture for Development 30, 25 - 28.

Machakaire, V., Turner, A. D. \& Chivinge, O. A. (2000) Agronomic and nutrition studies of two indigenous vegetables in Zimbabwe: Acta Horticulturae 513, 145 - 152.

MoFA (2007) Food and agriculture Sector Development policy (FASDEP II). Ministry of food and Agriculture, Accra.

Mabhaudhi, T., O'Reilly, P. \& Walker, S. (2016) The role of underutilised crops in Southern African farming systems: A scoping study.

Maroyi, A. (2011) Potential role of traditional vegetables in household food security: A case study from Zimbabwe. African Journal of Agricultural Research 6 (26), 5720-5728.

Mkonda, M. (2014) Rainfall variability and its Association to the trends of crop production in Mvomero district, Tanzania. European Scientific Journal 10 (20), 1857 - 7431.

Nyadanu, D., Aboagye, L. M., Akromah, R. \& Dansi, A. (2015) Agro-biodiversity and challenges of on-farm conservation: the case of plant genetic resources of neglected and underutilized crop species in Ghana. Genetic Resources and Crop Evolution DOI 10.1007/ s10722-015-0327-2. 
Ogbodo E.N. \& Onwa N.C. (2013) Impact of Longterm Application of Agrochemicals on the Agro-Ecology of the Lower Anambra River Basin Southeast Nigeria. Journal of Environment and Earth Science 3 (5), 32 37.

Omari, S. (2014) Assessing farmers' knowledge of effects of agrochemical use on human health and the environment: A case study of Akuapem South Municipality, Ghana. Int. Journal of Applied Sciences and Engineering Research 3 (2), 402 - 410. DOI: 10.6088/ ijaser.030200010.

Pesticide Action Network Europe (PAN) (2017) Alternative method to weed management to the use of glyphosate and other herbicides. Rue de la Pacification 67, 1000 Brussels, Belgium.
Stefanie, E. \& Amend, T. (2008) Development needs diversity: People, natural resources and International Cooperation - Contributions from the countries of the south. In: Sustainability Has Many Faces. (GTZ) Eschborn, Germany.

Shava, S., O’Donoghue, R., Krasny, M.E. \& Sebakwe, C.Z. (2009) Traditional food crops as a source of community resilience in Zimbabwe, International Journal of the African Renaissance 4 (1), 1-21.

Sharma, R. \& Bhardwaj, S. (2017) Effect of mulching on soil and water conservation - A review. Agricultural Reviews 38 (4), 311 - 315. 